\title{
MEMBENTUK GURU YANG BERMORAL, HUMANIS DAN PROFESIONAL MELALUI PROSES PSIKO-PEDAGOGIS
}

\author{
Muhammad Nur Wangid \\ Fakultas Ilmu Pendidikan, Universitas Negeri Yogyakarta \\ m_nurwangid@uny.ac.id
}

\begin{abstract}
Abstrak
Keinginan mewujudkan guru yang berkarakter sudah lama diinginkan. Setiap periode masa dan lembaga merumuskannya dalam termonologi yang beragam. Universitas Negeri Yogyakarta menginginkan menghasilkan calon guru yang bermoral, humanis, dan profesional pada saat ini. Untuk dapat menghasilkan calon guru yang berkarakter maka hendaknya dipahami terlebih dahulu hakekat guru yang akan dibentuk dan cara menanganinya. Guru pada hekekatnya bukanlah sekedar bertugas menyampaikan materi pelajaran kepada siswa. Guru memiliki tugas yang jauh lebih mulia yaitu mengembangkan aspek mental siswa sehingga menjadi manusia yang berbudipekerti luhur. Agar mencapai tujuan ini maka pelaksanaan pembelajaran diperguruan tinggi harus mempertimbangkan pula aspek pengembangan psikopedagogisnya. Optimalisasi aspek rohaniah mahasiswa dapat dilakukan dengan merujuk pada kemampuan (psikis) yang dimiliki manusia seperti yang dikemukakan oleh Bandura yang selanjutnya dikembangkan melalui proses pendidikan (pedagogis). Setiap jenis karakter yang diinginkan dikembangkan melalui pengintegrasian materi perkuliahan dan dilaksanakan secara berkelanjutan. Di samping itu seluruh civitas sebisa mungkin memberikan contoh, dan secara khusus dosen sendiri harus memberikan teladan bagi mahasiswa dalam keseharian pelaksanaan tugasnya. Ini adalah salah satu perspektif tugas yang harus dilaksanakan oleh setiap dosen dalam membentuk calon guru yang bermoral, humanis, dan profesional.
\end{abstract}

Kata kunci: membentuk guru, psikopedagogis

\section{BUILDING THE TEACHER MORAL, HUMANIST AND PROFESSIONAL THROUGH PSYCHO-PEDAGOGICAL}

\author{
Muhammad Nur Wangid \\ Fakultas Ilmu Pendidikan, Universitas Negeri Yogyakarta \\ m_nurwangid@uny.ac.id
}

\begin{abstract}
The desire to realize the teacher's character had long desired. Each period and institutions formulate in diverse terminology. Nowadays Yogyakarta State University want to produce teacher candidates who characterized moral, humane, and professional. In order to produce the prospective teachers it should be understood the characteristics of the teachers that will be set up and how to handle it first. The tasks of teachers is not just delivering course material to students. Teachers have a much more noble tasks to develop the spiritual aspects of the student so that they were to be humans noble character. In order to achieve this goal the implementation of learning in college should also considers the development of psycho-paedagogis aspects. Optimizing the spiritual aspects of the student can be done by referring to the ability (psychic) of human beings as proposed by Bandura, it all further developed through the process of education (paedagogical). Each type of character developed by integrated in lecture material and implemented continually. In addition, the entire community of college may give an example, and particularly the lecturers themselves should set the example for the students in the daily execution of their duties. It is one of perspective tasks that must be implemented by each lecturer in shaping future teachers that characterized by moral, humane, and professional.
\end{abstract}

Keywords: shaping teacher, psycho-paedagogis 


\section{PENDAHULUAN}

Manusia yang berkarakter merupakan sosok yang diidam-idamkan oleh semua pihak. Tidak ada pihak manapun juga yang tidak menginginkan terwujudnya sosok manusia yang berkarakter. Setiap keluarga menginginkan anaknya memiliki perilaku dan akhlak yang baik. Demikian halnya, instansi atau perusahaan mengharapkan karyawannya bersikap jujur, dan bersemangat, serta berkomitmen dalam bekerja. Dan bahkan masyarakat sendiripun pada hakekatnya mengharapkan warganya untuk saling menghormati, tertib, patuh pada aturan, bertoleransi dan sebagainya sehingga tercipta kedamaian dalam berkehidupan bermasyarakat.

Manusia yang berkarakter adalah hasil dari buah interaksi anak manusia dengan lingkungannya sepanjang hayatnya. Oleh karena itu, keluarga pada hakekatnya memiliki peran yang pertama dan utama dalam membentuk karakter anak. Lingkungan masyarakat tempat manusia hidup dengan sesamanya juga memiliki peran yang besar dalam membentuk karakter seorang anak. Satu lingkungan lagi yang sering menjadi tumpuan tempat mekar berkembangnya karakter adalah lingkungan sekolah. Namun demikian, kenyataan masyarakat sering menumpukan perkembangan karakter anak di sekolah. Bahkan seolah-olah hanya di lingkungan sekolah karakter anak akan berkembang. Hal ini karena orang tua/ wali siswa (masyarakat) sudah mempercayakan anaknya untuk di didik - dikembangkan karakternya di sekolah. Oleh karena itu sangat masuk akal sekolah dijadikan tumpuan keinginan masyarakat menjadikan atau menghasilkan sosok manusia yang berkarakter sesuai keinginan masyarakat setempat.

Keinginan melahirkan insan yang berkarakter tersebut sudah sejak dahulu. Bukti keinginan mewujudkan manusia yang berkarakter tersebut adalah terumuskannya dalam tujuan pendidikan Indonesia yang pertama tahun 1946. Menteri Pendidikan dan Pengajaran (Mr. Soewandi) membuat Surat Keputusan tanggal 1 Maret 1946 No. 104/Bhg.O untuk membentuk Panitia Penyelidik Pengajaran di bawah pimpinan Ki Hadjar Dewantara dan penulis Soegarda Purbakawatja. Salah satu hasil dari Panitia Penyelidik Pengajaran pada waktu itu adalah mengenai perumusan tujuan pendidikan. Tujuan pendidikan waktu itu dirumuskan untuk mendidik warga negara yang sejati bersedia menyumbangkan tenaga dan pikiran untuk negara dan masyarakat. Lebih jelas lagi tujuan pendidikan yang bernuansa karakter adalah Tujuan Pendidikan Indonesia Tahun 1950, yaitu membentuk manusia susila yang cakap dan warga negara yang demokratis, serta bertanggung jawab tentang kesejahteraan masyarakat dan tanah air (Departeman Pendidikan dan Kebudayaan, 1979, pp. 95-97).

Demikian pula keinginan mewujudkan insan yang berkarakter tetap menggelora seperti tujuan hidup berbangsa dan bernegara yang termuat dalam Undang-Undang No. 20 tahun 2003 tentang Sistem Pendidikan Nasional pasal 3 yaitu “....bertujuan untuk berkembangnya potensi peserta didik agar menjadi manusia yang beriman dan bertakwa kepada Tuhan Yang Maha Esa, berakhlak mulia, sehat, berilmu, cakap, kreatif, mandiri, dan menjadi warga negara yang demokratis serta bertanggung jawab". Hal ini berarti bahwa pendidikan sepanjang masa selalu mengharapkan hasil pendidikan tidak hanya berupa kemampuan-kemampuan kognitif akademis (hard skill) namun juga berupa kemampuankemampuan yang bersifat soft skill yang berupa nilai-nilai, sikap, dan moral. Masalahnya bagaimana bisa mewujudkan cita-cita yang mulia ini, manusia yang dipenuhi nilainilai kemanusiaan, bersikap profesional, dan menjunjung nilai-nilai moral. Oleh karena itu, salah satu langkah untuk bisa melahirkan insan yang bermoral, humanis, dan profesional adalah harus mengadakan guru yang bermoral, humanis, dan profesional terlebih dahulu. Dengan kata lain, bagaiman menciptakan guru yang berkarakter, humanis, dan profesional? Dalam konteks inilah peran dan tugas Universitas Negeri Yogyakarta (UNY) sebagai Lembaga Pendidik Tenaga Kependidikan (LPTK) mempunyai peta strategi menghasilkan pendidik yang bermoral, humanis dan profesional.

\section{PEMBAHASAN}

Guru dari Sanskerta yang secara harfiahnya artinya adalah "berat", secara terminologi umum guru adalah seorang pengajar suatu ilmu. Dalam bahasa Indonesia, guru umumnya merujuk pendidik profesional dengan tugas utama mendidik, mengajar, mem- 
bimbing, mengarahkan, melatih, menilai, dan mengevaluasi peserta didik. Sedangkan Sedgwick (2008, p.7) menjelaskan seorang guru adalah orang dewasa dengan kualifikasi tertentu yang 'menunjukkan (show)' pengetahuan anak, biasanya di sekolah .

Menurut Undang-Undang Guru dan Dosen Nomor 14 tahun 2005 pasal 1 disebutkan bahwa "Guru adalah pendidik profesional dengan tugas utama mendidik, mengajar, membimbing, mengarahkan, melatih, menilai, dan mengevaluasi peserta didik pada pendidikan anak usia dini jalur pendidikan formal, pendidikan dasar, dan pendidikan menengah". Penjelasan ini memberikan penjelasan bahwa guru memiliki tugas utama dan pertama sebagai pendidik. Pendidik tersebut haruslah profesional, artinya dalam bekerja harus menegakkan nilai-nilai profesionalitas. Oleh karena itu, guru tidak hanya mengajar dan memberikan nilai untuk kenaikan atau kelulusan semata. Jauh lebih bermartabat dari itu pendidik adalah orang dewasa yang bertanggungjawab memberikan bimbingan kepada peserta didik dalam perkembangan jasmani maupun rohaninya agar mencapai tingkat kedewasaan (maupun berdiri sendiri) memenuhi tugasnya sebagai mahluk Tuhan. mahluk individu yang mandiri dan mahluk sosial.

Untuk dapat menjadi pendidik yang baik minimal harus ada dua unsur dasar yang harus dipenuhi, yaitu adanya kasih sayang, dan kedua adalah kesadaran bertanggung jawab untuk membantu perkembangan anak yang termanifestasikan dalam kewibawaan (kekuasaan batiniah/mental pendidik) sebagai pendidik. Dalam konteks inilah kewibawaan sering disebut sebagai prasyarat untuk terjadinya proses pendidikan. Hal ini karena kewibawaan justru merupakan suatu pancaran batin yang dapat menimbulkan kepada pihak lain, sikap untuk mengakui, menerima dan menuruti dengan penuh pengertian atas kekuasaan. Kewibawaan timbul jika seseorang sudah dewasa baik jasmani maupun rohani, dewasa rohani bila individu telah memiliki cita-cita hidup dan pandangan hidup yang tetap (nampak dalam tingkah laku dan perbuatan), dan secara formal ditunjukkan dengan bukti formal legal yang berupa ijasah sebagai bentuk pengakuan bahwa yang bersangkutan telah memiliki kompetensi untuk memikul tanggung jawab dan melaksanakan tugas profesi pendidik, Santrock (2011, p. 6) menyebut dengan professional knowledge and skills. Yang bermakna bahwa guru harus profesional dalam penguasaan substantif dan harus menguasai ketrampilan-ketrampilan dalam menyampaikan materi dengan dibingkai dalam kegiatan mendidik. Dari perspektif ini maka hakikat guru sebagai pendidik adalah (Msila, 2012; Harden and Cosby, 2000): (1) Pendidik sebagai agen pembaruan, artinya pendidik adalah sumber dari ide-ide pembaharuan kemudian ide-ide pembaruan itu hendaknya dapat disebarluaskan oleh pendidik sebagai bentuk layanan kompetensinya, (2) Pendidik adalah pemimpin dan pendukung nilai-nilai masyarakat, maksudnya pendidik seharusnya terlebih dahulu menjadi orang yang menghayati dan mengamalkan nilai-nilai masyarakat. Lebih jauh lagi pendidik diharapkan dapat melanjutkan nilai-nilai tersebut kepada subjek didiknya, dan masyarakat pada umumnya, (3) Pendidik sebagai fasilitator berkewajiban menata lingkungan sehingga memungkinkan terciptanya kodisi yang baik bagi peserta didik untuk belajar, misalnya dalam proses belajar mengajar peserta didik yang aktif belajar, peranan pendidik menyediakan sumber bahan dan media yang diperlukan dalam kegiatan tersebut, (4) Pendidik bertanggungjawab dan berkewajiban membimbing atas pencapaian hasil belajar siswa peserta didik, (5) Pendidik dituntut untuk menjadi contoh ketika mengelola proses belajarmengajar khususnya bagi calon guru yang menjadi peserta didik.

\section{Proses Pembentukan Guru Melalui Proses Psiko-Pedagogis}

Universitas Negeri Yogyakarta sebagai LPTK mempunyai tugas untuk mempersiapkan tenaga pendidik dan non pendidik (kependidikan). Sebagai instansi yang bertugas membentuk dan melahirkan tenaga pendidik sudah selayaknya menyandarkan prosesnya pada teori-teori belajar yang sudah mapan. Pada kesempatan ini untuk membahas proses pembentukan guru adalah teori sosial kognitif dari Bandura (1986). Teori ini menetapkan tingkah laku manusia sebagai suatu tritunggal yang dinamis dan saling berinteraksi, yaitu antara faktor personal, faktor tingkah laku, dan faktor lingkungan. Oleh karena itu, menurut teori ini suatu tingkah laku individu secara unik ditentukan oleh 
ketiga faktor di atas. Dari perspektif ini maka perilaku (performance) mahasiswa calon guru hakekatnya juga merupakan hasil interaksi antara faktor pribadi, tingkah laku, dan lingkungan. Lingkungan tempat mahasiswa belajar/kuliah menempa diri menjadi calon pendidik memiliki peran yang cukup signifikan. Lingkungan tempat kuliah terdiri dari faktor sosial dan non sosial. Faktor sosial adalah lingkungan tempat mahasiswa berhubungan sosial (sesama manusia) dengan siapa saja dalam lingkungannya. Di kampus lingkungan sosial ini terdiri dari antara lain sesama mahasiswa, dosen, karyawan, dan masyarakat lingkungan kampus. Faktor non sosial adalah lingkungan mahasiswa tempat beraktivitas yang bersifat non manusia (sosial). Lingkungan tempat manusia beraktivitas berupa lingkungan fisik alami dan lingkungan fisik buatan. Lingkungan fisik alami berupa kondisi alam, geografis, iklim, cuaca, dan sebagainya. Kondisi lingkungan fisik buatan berupa bangunan gedung, berbagai piranti untuk beraktivitas: meja, kursi, komputer, laptop, kertas, pulpen, dan sebagainya. Semua kondisi lingkungan ini akan berpengaruh pada diri pribadi mahasiswa, dan berpengaruh pula secara langsung pada perilaku mahasiswa.

Lingkungan sosial secara langsung atau tidak langsung akan mempengaruhi pribadi mahasiswa. Dosen secara langsung berinteraksi dengan mahasiswa dalam proses perkuliahan. Proses komunikasi dan interaksi secara langsung akan memberikan berbagai dampak dalam pribadi mahasiswa. Jenis, bentuk, dan intensitas komunikasi akan ditangkap secara langsung dan bersifat timbal balik dengan dosen. Interaksi dan komunikasi antara dosen dan mahasiswa secara langsung akan mendorong timbulnya reaksi perilakuperilaku baru atas aksi yang dilakukan oleh satu pihak (dosen) kepada pihak lain (mahasiswa). Reaksi-reaksi atau respon-respon yang dilakukan Inilah bukti bahwa sebenarnya terjadi interaksi timbal balik antara diri pribadi, lingkungan, dan perilaku itu sendiri.

Pendapat Bandura tentang teori kognitif sosial meliputi aspek sosial dari lingkungan dan proses kognitif dari manusia. Oleh karena itu untuk membentuk calon guru yang bermoral, humanis dan profesional harus dilakukan dalam konteks sosial, dan melalui proses-proses kognitif sebagai bentuk proses internalisasi berbagai bentuk karakter yang akan ditanamkan. Sehubungan dengan itu, maka ada beberapa asumsi tentang kemampuan yang dimiliki mahasiswa yang harus dikembangkan (Bandura, 1986, pp. 18-21), yaitu sebagai berikut.

\section{Kemampuan Menyimpulkan (Symbolizing Capability)}

Teori kognitif sosial tetap menganggap bahwa sebagian besar pengaruh-pengaruh dari luar mempengaruhi tingkah laku melalui proses-proses kognitif. Kemampuan menyimbolkan (symbolizing capability) memberikan suatu mekanisme untuk berfikir. Melalui formasi simbol-simbol, seperti bayangan (gambaran mental) atau kata-kata, mahasiswa sanggup memberikan makna, bentuk, dan membuat hubungan-hubungan diantara pengalaman-pengalamannya. Kemampuan untuk membentuk simbol-simbol ini memungkinkan manusia menyimpan informasi di dalam ingatannya yang dapat digunakan untuk membimbing tingkah lakunya lebih lanjut. Melalui proses ini manusia sanggup untuk menirukan tingkah laku yang dilihatnya.

Dengan menggambarkan suatu kondisi dalam pikiran dan menggunakan kemampuan menyimbolkan maka mahasiswa dapat menghasilkan tindakan yang inovatif. Masalah moral atau karakter tidak selalu dapat diekperimenkan. Pengalaman menangani masalah moral atau masalah kemanusiaan tidak setiap saat dan setiap mahasiswa akan dapat mengamai secara langsung. Melalui kemampuan ini dosen seharusnya mampu memberikan permasalahan-permasalahan karakter yang bersifat imaginatif kepada mahasiswa. Dengan kemampuannya menyimbolkan mahasiswa akan berimaginasi sesuai kemampuannya sendiri-sendiri untuk mendiskripsikan tugas moralnya sebagai acuan bertindak. Misalnya masalah moralitas atau kemanusiaan dapat diberikan dengan memberikan kasuskasus yang harus ditangani mahasiswa secara individu ataupun bersama-sama. Kemampuan menghubung-hubungkan kondisi pribadi dengan kasus yang harus dipecahkan merupakan bentuk kemampuan menyimbolkan dalam dalam rangkaian tugas atau kegiatan yang bermuara pada penyelesaian permasalahan yang dihadapi. Suatu kondisi yang sangat bermanfaat jika mahasiswa memang belum pernah atau tidak mungkin menghadapinya secara langsung. 
Kemampuan Mengandaikan Pengalaman (Vicarious Capability)

Pandangan kognitif sosial berasumsi bahwa belajar dapat terjadi melalui pengalaman yang seolah-olah mengalami (vicarious), sebaik pengalaman langsung, dengan mengobservasi tingkah laku orang lain dan akibat dari tingkah laku itu, manusia dapat belajar bahwa tingkah laku itu efektif atau tidak. Observasi yang demikian memungkinkan manusia untuk membangun pengetahuan dan kemudian mempergunakan kemampuan menyimbolkan untuk merencanakan suatu tindakan. Kemampuan seolah-olah mengalami ini memberikan suatu keuntungan yang besar bagi manusia, karena dapat belajar dengan memperhatikan kesuksesan dan kegagalan orang lain, sehingga manusia tidak harus belajar segala sesuatunya secara langsung melalui usaha yang sifatnya trial and error. Manusia tidak perlu menghabiskan banyak waktu untuk memperoleh pengalaman. Maka, kemampuan ini sangat penting bagi manusia karena memungkinkan manusia membentuk suatu pola tingkah laku secara cepat, menghindari penggunaan waktu hanya untuk mencoba-coba, menghindari hal-hal yang merugikan, dan menghindari kesalahan yang fatal. Oleh karena itu kemampuan seolaholah mengalami ini memungkinkan manusia untuk mengeksplorasi situasi dan aktivitasaktivitas untuk memperoleh pengetahuan baru yang secara normal diluar jangkuan karena hambatan waktu, sumber dan jarak.

Kemampuan sangat bermanfaat bagi mahasiswa tatkala mereka harus mengerjakan sesuatu yang belum dikerjakan. Misalnya menjadi seorang guru, tidak semua mahasiswa telah memiliki pengalaman ini dengan baik. Melalui kemampuan mengandaikan pengalaman ini mahasiswa dapat berlatih menjadi guru mulai dari sekedar melihat contoh bagaimana menjadi seorang guru melalui demonstrasi atau rekaman video sampai dengan melihat atau mengobservasi guru yang sedang mengajar di kelas. Pengalaman melihat berbagai model atau contoh ini akan menambah akumulasi pengetahuan tentang profesionalitas guru melalui pengamalan tidak langsung. Walaupun tidak langsung akan sangat memberi manfaat bagi mahasiswa karena akan semakin banyak terhindar dari kesalahan-kesalahan fatal yang mungkin akan diperbuatnya. Untuk ini, maka mahasiswa memerlukan banyak contoh ataupun deskripsi yang menggambarkan bagaimana menjadi guru yang bermoral, humanis dan profesional.

\section{Kemampuan Memperkirakan (Forethought Capability)}

Menurut teori kognitif sosial sebagian besar tingkah laku manusia adalah bertujuan dan diatur dengan kemampuan memperkirakan. Kemampuan memperkirakan merupakan suatu kemampuan manusia untuk memotivasi dirinya sendiri dan membimbing tingkah lakunya secara antisipatif. Manusia tidak sematamata bereaksi terhadap lingkungan di sekitarnya saja, tetapi perilakunya juga dibimbing oleh pengalaman masa lalunya. Dengan menggunakan pengetahuan dari masa lalu, manusia mampu memikirkan suatu kejadian sebelumnya (forethought), mengantisipasi masa depan. Mereka dapat mempertimbangkan kemungkinan-kemungkinan cara dari tindakan dan mengantisipasi hasil dari tindakan itu. Orang dapat menetapkan tujuan bagi bagi dirinya sendiri, dan merencanakan masa depan sebagai suatu rencana kegiatan yang akan dilakukan.

Mahasiswa mampu memprediksi suatu peristiwa yang telah dirancangkan, hal ini merupakan rangkaian dari kemampuan menyimbolkan dan mengandaikan. Melalui kemampuan ini sudah semestinya mahasiswa akan dapat merancang bentuk-bentuk perilaku yang sesuai dengan nilai-nilai moral, humanitas dan profesionalitas. Namun demikian kemampuan merancang suatu kegiatan atau peristiwa ini tidak bisa terlepas dari pengaruh lingkungannya. Dari sisi ini maka sebenarnya betapa penting peran dari pendamping (lingkungan) baik dari dosen, teman, atau karyawan yang didukung dengan kondisi lingkungan yang memadahi. Ketiadaan dukungan lingkungan untuk merancang kegiatan atau peristiwa yang penuh bernuansa dengan nilainilai moral, kemanusiaan, dan profesionalitas menjadikan mahasiswa tumpul pada suasana nilai moral, kemanusiaan, dan profesionalitas. Oleh karena itu, jika diyakini bahwa mahasiswa memang memiliki rancangan kegiatan yang dapat mengembangkan nilai-nilai moralitas, kemanusiaan, dan profesionalitas harus didukung secara penuh oleh semua pihak untuk mewujudkannya. 
Kemampuan Mengatur Diri (Self-Regulatory Capability)

Teori social kognitif berasumsi bahwa manusia bertingkah laku tidak hanya semata-mata untuk memuaskan orang lain atau lingkungannya, namun juga untuk memuaskan kebutuhannya sendiri. Untuk mencapai tujuan itu, manusia mengembangkan teknik self-regulation (mengatur diri), dengan menerapkan seperangkat standar internal dan reaksi evaluatif terhadap perilaku mereka sendiri. Melalui reaksi-reaksi evaluasi diri, mereka sanggup mendeteksi ketidaksesuaian antara kinerja dan standar tingkah laku internalnya. Melalui tindakan-tindakan yang khusus dan mengevaluasi tindakantindakan itu terhadap standar kinerja pribadinya, mereka sanggup menyesuaikan tingkah lakunya. Walaupun tingkah laku tidak diragukan lagi dipengaruhi oleh orang lain dalam lingkungannya, Bandura (1986, 20) juga berasumsi bahwa kemampuan-kemampuan internal individu yang menghasilkan tingkah laku juga memiliki peran yang tidak kecil. Sebagai contoh, siswa-siswa SMP atau SMU biasanya ada di bawah tekanan sosial kelompoknya, tetapi tidak setiap remaja itu tunduk pada tekanan kelompoknya. Kemampuan mengatur diri merupakan suatu mekanisme kontrol internal yang menentukan apakah suatu tingkah laku dilakukan, dan memberikan konsekuensi bagi suatu tingkah laku. Kemampuan mengatur diri ini sangat penting karena memungkinkan secara bertahap mengganti kontrol tingkah laku eksternal manjadi internal. Sistem self-regulatory ini mengantarai pengaruh-pengaruf eksternal dan memperlengkapi suatu dasar tingkah laku tertentu, sehingga memungkinkan manusia mengontrol seluruh pikiran, perasaan, motivasi dan tingkah lakunya.

Kemampuan mahasiswa untuk mengatur diri sendiri berdasarkan standar internal menjadi sangat penting tatkala berhubungan dengan standar-standar moralitas, kemanusiaan, dan profesionalitas. Artinya bahwa mahasiswa sebagai calon guru akan mampu atau tidak mempertimbangkan suatu perbuatan terkait dengan standar-standar moral, kemanusiaan, dan profesionalitas. Barangkali nilainilai tersebut mudah diucapkan namun ketika menemukan dalam proses permasalahan yang cukup kompleks maka sering standar-standar tersebut berubah untuk disesuaiakan dengan kondisi permasalahan yang dihadapi. Bahkan menjadi standar pribadi yang sama sekali berbeda dengan ukuran normatifnya.

Pada tahap inilah sebenarnya nilainilai moralitas, kemanusiaan, dan profesionalitas mahasiswa maupun dosen diuji untuk ditentukan kadar kualitasnya. Kemampuan mengatur diri bertingkah laku dengan standar internal yang telah dipegang teguh berdasarkan nilai-nilai kebenaran eksternal yang universal akan menjadikan kualitas diri pribadi semakin tinggi. Namun sebaliknya, ketidakmampuan mengatur perilaku sendiri untuk berpegang standar nilai internal berdasar pada kebenaran eksternal akan membawa pada penurunan derajat kualitas pribadi. Dari perspektif ini semua pihak dituntut untuk dapat memegang teguh nilai-nilai pribadi yang telah direferensikan kebenarannya pada standar eksternal yang bersifat universal. Dengan kata lain dosen, mahasiswa, karyawan, dan semua pihak yang lain dituntut untuk mampu mengendalikan diri berperilaku sesuai dengan kata hati tentang kebenaran yang universal baik terkait dengan nilai moral, kemanusiaan, dan profesionalitas. Jika ini mampu dilakukan oleh semua pihak maka ketertiban, kedamaian, kesejahteraan, dan kebahagiaan akan dirasakan semua pihak.

\section{Kemampuan Merefleksikan Diri (Self- Reflective Capability)}

Kemampuan merefleksikan diri (selfreflection) memungkinkan orang untuk menganalisis pengalamannya, memikirkan tentang proses berfikirnya, dan dimungkinkan mengganti pemikiran itu. Kemampuan merefleksikan diri tidak menjamin bahwa di masa depan tindakannya selalu berakibat positif. Jika manusia memiliki satu keyakinan yang salah, keyakinan ini dapat mengarahkan saja pada pemikiran yang salah pula, dan oleh karenanya tindakannya juga salah.

Mahasiswa sebagai individu yang telah berkembang mendekati kedewasaan telah memiliki berbagai kemampuan yang relatif sempurna. Berbekal berbagai kemampuan tersebut maka mahasiswa mampu merefleksi berbagai kegiatan atau pengalaman yang telah dilakukannya. Kemampuan merefleksikan sangat penting artinya untuk perkembangan karakter. Pengalaman-pengalaman pribadi atau berbagai peristiwa di masyarakat yang 
terkait dengan nilai moral, kemanusiaan, dan profesionalitas akan dapat dilihat kembali dan dinilai kebenarannya. Kemampuan menilai suatu masalah dengan tapat dan benar memiliki peran yang sentral dalam menentukan bentuk perilaku atau perkembangan berikutnya. Hal inilah yang harus diperhatikan khususnya para dosen untuk dapat memberikan pertimbangan dan kritik atas pilihan mahasiswa terkait perilaku moralitas, kemanusiaan, dan profesionalitas.

\section{Esensi Moralitas, Humanis dan Profesional dan Pengembangannya}

Pengembangan setiap jenis karakter pada hakekatnya tidak bisa dipisah-pisahkan. Gold (2005, pp. 162-166) menjelaskan bahwa ada dua dimensi yang perlu diperhatikan dalam pengembangan guru, yaitu dimensi pembelajaran (instructional domain) dan dimensi psikologis (psychological domain). Penekanan aspek-aspek psikologis dalam pembelajaran sangat penting. Peristiwa seharihari akan memberikan pengalaman psikologis yang kuat dalam pribadi individu. Oleh karena itu, pengembangan karakter sudah semestinya mempertimbangkan aspek psikologis ini dalam pelaksanaannya. Bahwa sekarang mahasiswa barangkali masih mencontoh karakter tersebut namun lain waktu dirinya akan dicontoh oleh muridnya. Berikut dibahas substansi materi pengembangan moralitas, humanis (kemanusiaan), dan profesionalitas.

\section{Moral}

Kata moral sering dipergunakan untuk menyebut jenis kualitas perilaku seseorang. Jika seseorang berinteraksi dengan orang lain menunjukkan kualitas perilaku yang positif maka orang tersebut akan dikategorikan bermoral, dan jika sebaliknya dalam berinteraksi dengan orang lain menunjukkan kualitas yang negatif maka orang tersebut akan dinilai amoral. Standar moral dipakai untuk menentukan apakah suatu perilaku termasuk bermoral ataukah amoral. Standar moral yang dipakai adalah hasil dari kesepakatan budaya masyarakat dann agama lazimnya. Oleh karena itu moral adalah sesuatu yang harus dimiliki oleh seseorang. Hal ini karena nilai-nilai moral sangat berhubungan kegiatan sosialisasi yang dilakukan manusia di lingkungannya. Mengingat arti pentingnya moral ini maka nilai-nilai moral ini selalu diajarkan dalam setiap jenjang pendidikan. Mengingat yang disampaikan adalah nilai-nilai dasar kehidupan maka setiap pendidik bertugas menyampaikannya kepada peserta didik. Pengembangan dilakukan secara terus-menerus dalam model yang terintegrasi dengan kegiatan pembelajaran yang dilakukan oleh guru. Hal-hal yang mendorong berkembanganya moralitas dikembangkan dan yang bersifat amoral ditumpas. Misalnya, mahasiswa berkata jujur selalu didorong, sedangkan mahasiswa berdusta tidak diperbolehkan/dilarang. Sekali lagi karena menyampaikan nilai-nilai moral pada hakekatnya adalah tugas semua anggota masyarakat apalagi guru/pendidik.

\section{Humanis}

Humanis adalah nilai dasar kehidupan. Maksudnya adalah bahwa setiap manusia harus dan layak dihargai, serta tidak boleh dihilangkan semena-mena. Dengan demiakian nilai-nilai humanis (kemanusiaan) adalah terkait dengan pandangan atau sikap seseorang memperlakukan orang lain. Semakin akomodatif seseorang terhadap keberadaan orang lain maka akan semakin tinggi nilai humanitasnya, sebaliknya semakin sempit penerimaan seseorang terhadap orang lain maka sikap kemanusiaannya juga semakin rendah apalagi sampai menghilangkan hak hidup orang lain. Oleh karena itu, sama dengan pengembangan nilai-nilai moralitas pengembangan nilai-nilai kemanusiaan juga sangat penting bagi bekal kehidupan untuk berinteraksi dengan orang lain. Dimulai dengan sikap dari dosen untuk akomodatif pada semua mahasiswanya maka mahasiswa akan dapat melihat dan mencontoh bagaimana memperlakukan orang lain. Dilanjutkan dengan bersama-sama antara dosen dan mahasiswa melakukan kegiatan yang bernilai kemanusiaan. Dari praktek semacam ini mahasiswa akan dapat contoh dan pengalaman langsung melakukan kegiatan-kegiatan kemanusiaan. Aktivitas yang bernuansa kemanusiaan didorong dikembangkan dan sebaliknya yang negatif dilarang. Misalnya menolong orang lain dalam konteks yang benar didorong untuk dilakukan, sedangkan tindakan bullying pada teman dilarang. 
Profesional

Seorang profesional lazimnya adalah anggota dari sebuah profesi. Istilah ini juga menggambarkan standar pendidikan dan pelatihan yang mempersiapkan anggota profesi dengan pengetahuan dan keterampilan tertentu yang diperlukan untuk melakukan peran profesi itu. Selain itu, sebagian besar profesional tunduk pada kode etik yang ketat mengabadikan kewajiban etika dan moral yang ketat. Standar profesional dan etika praktek untuk bidang tertentu biasanya disepakati dan dipertahankan melalui asosiasi profesional yang diakui secara luas. Meskipun demikian orang-orang yang memiliki keahlian dalam suatu bidang juga disebut "profesional" dalam bidangnya meskipun bukan merupakan anggota sebuah entitas yang didirikan dengan sah. Sebagai contoh, dalam dunia olahraga terdapat olahragawan profesional yang merupakan kebalikan dari olahragawan amatir yang bukan berpartisipasi dalam sebuah turnamen/kompetisi demi uang. Sullivan (2005) menjelaskan batas profesional istilah ini untuk profesi mereka yang melayani beberapa aspek penting dari kepentingan publik dan kebaikan umum masyarakat. Profesionalitas menjadi salah satu tuntutan dikehidupan jaman modern. Oleh karena itu dosen hendaknya membiasakan mahasiswa untuk berperilaku yang sesuai dengan nilai-nilai profesional, seperti produktif, efektif, efisien, dan sebagainya. Sebagai salah satu contoh pengembangan profesionalitas adalah memberdayakan mahasiswa untuk dapat berkarya sesuai dengan kompetensinya, artinya mahasiswa haruslah produktif - menghasilkan sesuatu, bukan sebaliknya yang hanya sekedar menggunakan atau memakai semata (konsumtif).

\section{PENUTUP}

Sebagai catatan akhir, mahasiswa sebagai calon guru harus dibiasakan dengan sifat-sifat yang mulia yang merupakan karakteristik pendidik yang idam-idamkan yaitu bermoral, humanis, dan profesional. Bermoral merupakan karakteristik individu dalam bersosialisasi, jika dalam bersosialisasi mahasiswa menunjukkan perilaku yang akhlak mulia dan dipersepsikan oleh orang lain positif maka dirinya sudah bermoral. Untuk itu, perguruan tinggi adalah menyediakan contoh perilaku akhlak yang mulia dari seluruh civitas akademikanya, menyediakan regulasi yang jelas tentang bentuk tatakrama yang harus dilakukan di lingkungan kampus, dan mendorong dilaksanakannya praktek ahklak yang mulia. Humanis merupakan bentuk sifat akomodatif individu pada individu lain. Kebiasaan menerima perbedaan dalam kehidupan dan memperlakukan orang lain tanpa diskriminasi adalah kunci humanitas individu. Sedangkan profesional adalah mengerjakan tugas sebaik-baiknya sesuai dengan kompetensi yang dimiliki dengan penuh semangat dan komitmen yang tinggi. Agar mahasiswa terbiasa memiliki sifat kemanusiaan dan profesionalitas yang tinggi maka diperlukan standar kinerja yang jelas disertai contoh pelaksanaan. Dengan demikian pada hakekatnya pembentukan manusia yang berkarakter yang dikehendaki harus dimulai dari diri pribadi setiap civitas akademika untuk menjamin pembiasaan perilaku berbudi pekerti mulia. Di samping secara khusus, bagi dosen memberikan teladan kepada mahasiswa dalam berinteraksi kesehariannya. Oleh karena itu, sekali lagi tatakrama kehidupan perguruan tinggi perlu ditegakkan, sehingga diharapkan akan menghasilkan calon guru yang sudah terbiasa berperilaku santun, toleransi yang tinggi, serta produktif - inilah hakekat manusia yang bermoral, humanis dan profesional

\section{DAFTAR PUSTAKA}

Bandura, Albert. 1986. Social foundations of though and action: a social cognitive Theory. New York: Nj. Prentice-Hall.

Departemen Pendidikan dan Kebudayaan. 1979. Pendidikan Di Indonesia Dari Jaman Ke Jaman. Jakarta: Badan Penelitian dan Pengembangan Pendidikan dan Kebudayaan.

Gold, Yvonne. 2005. "The Psychological Dimensions of Teacher Education: The Role of the University" dalam The Role of the University in the Preparation of Teachers. Editor Robert A Roth. Hal. 162 -175.

Harden, R M and Crosby, J R .2000. " The good teacher is more than a lecturer the twelve roles of the teacher". Medical Teacher. 22 (4): 334-347. 
Msila, Vuyisile. 2012. The Teacher as Leader: The Challenge of Diverse Classrooms. Journal of Educational and Social Research. Vol. 2 (1) January 2012.

Santrock, John W. 2011. Educational psychology. New York: Mc Graw Hill.
Sedgwick, Fred. 2008. So you want To Be A Teachers? Singapore: Sage.

Sullivan, William M. .2005. Work and Integrity: The Crisis and Promise of Professionalism in America. Jossey Bass. 